\title{
Smartphones as a New Paradigm in Higher Education Overcoming Obstacles
}

\author{
https://doi.org/10.3991/ijim.v11i4.6759 \\ Mansour Alwraikat \\ The University of Jordan, Amman, Jordan \\ mansouralwraikategmail.com
}

\begin{abstract}
This study will investigate obstacles hindering graduate students use of smartphones in their learning at The University of Jordan. The study employed a descriptive survey research method using a self-administered 21-item questionnaire. Out of the entire population of 1,100 graduate students from the School of Educational Sciences, a randomly purposeful sample of 227 was selected. Individuals within the sample owned smartphones. A total of 108 students responded to the questionnaire. This was $45 \%$ of the original study sample during the first semester of the 2016-2017 academic year. The validity and reliability of the questionnaire were both secured. The study's findings showed that the overall degree level of obstacles reported by graduate students was high. In addition, there were no statistically significant differences in student estimates of obstacles due to their gender, age, place of work, first degree (BA), or computer skills. The researcher offered suggestions for overcoming these obstacles in light of the student estimates.
\end{abstract}

Keywords-Mobile Learning, Smartphone, Students, Obstacles, The University of Jordan

\section{$1 \quad$ Introduction}

In recent years, the world has witnessed widespread use of various smartphones, a term given to a class of modern mobile phones using sophisticated operating systems. These include the Apple iPhone, Samsung Galaxy, BlackBerry, LG, Motorola, Nokia, and Sony (ITU news, 2011). Most smartphones use a touch-screen user interface and run mobile applications. Manufacturers do not agree on a common definition for the smartphone.

Smartphone features include internet access, synchronization of e-mail, opening of Microsoft Office files, and full-keyboard access (QWERTY). The most widely accepted definition is that the mobile is powered by one of the following operating systems: Windows, Symbian (or its derivatives), Linux (or its derivatives), and Blackberry. Smartphones are no different than laptops, personal computers, or other devices. Smart devices consist of two parts that are complementary to each other. These are the hardware, a physical part responsive to touch, and the software as a programmatic 
device operator (operating system) to lead the hardware. Similar to Windows and Linux, the smartphone device will not work without an operating system.

The emergence of m-learning and the advancement of smartphones were a driving factor in the development of learning methods. These new methods focused on the role of the learner, as well as the learner's capabilities and skills. It did not rely on the teacher, which allowed the student to step into the role of participant rather than receiver. The student was no longer entirely dependent upon the teacher. Through selflearning, the student became self-reliant. This practical learning method is in line with modern educational trends. Consistent with learning economies, the method saves time, effort, and money while strengthening the student's learning abilities (Arabiat \& Adaileh, 2008).

m-Learning via smartphones occurs without borders and at any time (i.e., the student can be in an office, at home, etc.). This type of education increases learning opportunities, allows a learning to obtain qualifications and scientific degrees in different majors, and gives students an opportunity to study under any circumstance and/or issue. Moreover, this system considers pattern differences between students. Therefore, the student can work at an individual and suitable pace. The student's technical knowledge is strengthened, which increases the wealth of knowledge throughout societies. This, in turn, results in comprehensive economic, social, and cultural developments of a society (Abdelmajid, 2008).

The University of Jordan supports interaction and harmony with new global ideas and educational trends. In its efforts to gain a global reputation, the university is integrating m-learning via smartphones into its academic environment. The university has an upstanding reputation for graduating capable students who will serve in different sectors of the Jordanian society (The Univercity of Jordan, 2016).

The university's challenges are manifested in a noticeable increase in the number of students enrolled in academic programs, especially parallel international program. There is also a growing trend to use modern technology in teaching, communicating, and electronic evaluation. This impacts various disciplines, such as health, scientific, and human studies. Undoubtedly, there is importance in a university student's contribution to improved quality and output performance. Therefore, the basic element in the classroom is the student. Student responses are reactions to represented behaviors which vary according to behaviors at the university (Alhourani \& Tanash, 2007).

\subsection{Obstacles with Smartphones in Learning}

Dewey (1916, p. 88) stated:

A society which is mobile, which is full of channels for the distribution of a change occurring anywhere, must see to it that its members are educated to personal initiative and adaptability. Otherwise, they will be overwhelmed by the changes in which they are caught and whose significance or connections they do not perceive.

Despite massive advances in the smartphone industry, availability of services, and accessibility to effective learning, there are obstacles to the employment of smartphones in education. Referring to mobile devices as smartphones, Waters (2009) emphasized difficulties in controlling the uncontrollable. In fact, the lack of a widely- 
accepted and practiced learning theory prevents the evolution of smartphone applications into education.

It is important to identify smartphone features supporting the process of learning, the context of learning, and learners who would benefit from the system (Deubel, 2009). If these are not identified, learning will continue to be viewed as a technologymediated process where knowledge is formed through discussions and exchanges (Sharples, Taylor, \& Vavoula, 2006).

A group of researchers noted that the small size of the smartphone is a burden because: the learner tilts their posture; the screen displays reduced amounts of information and strains the eyes; it is difficult to type or enter data; there is a short battery life; and it has modest storage (Alhalafawi, 2011; Alkhozim, 2012; Sahtot, 2014; Suki $\&$ Suki, 2011). The large number of models, companies, and multiple operating systems leads to a lack of quick familiarity with the hardware. The smartphone is considered to be less powerful than office equipment, as well as easily lost or stolen. Students may feel isolated by using a smartphone. There is a digital divide between devices and students who are not proficient in technology. It is important to have learners and teachers who have adequate training. In addition, evolution makes devices quickly outdated.

Mehdipour and Zerehkafi (2013) noted additional obstacles related to mobile learning through smartphones, including: student obsession with devices during class; sending and/or receiving entertainment messages from colleagues; isolation from teachers; lack of attention when the teacher is speaking; and a decrease in academic achievement. The adoption of this technology in the educational process may limit student creativity and innovation.

Smartphones increased cheating among students in exams via text messages sending and/or receiving answers through services like Bluetooth. Furthermore, students share inappropriate content or cause distractions with a phone ringing during class (Suki \& Suki, 2011). Smartphones also provide another means for cyberbullying. Health risks due to excessive use of smartphones have resulted in the banning of their use in some educational institutions. Shuler (2009) explicated the potential distraction, unethical behavior, physical health concerns, and data privacy issues.

Learning via smartphones has been considered an innovative and effective method. Educational institutions that apply m-learning and distance learning methods are often considered open and continuous training centers without barriers. For this reason, resolving obstacles surrounding this type of learning has become noteworthy.

One issue to resolve is the problem facing students. Reports show a lack of university student involvement in the potential role that smartphones serve in the educational learning process (Aldahshan \& Younis, 2009; Pollara, 2011). Students continue to use ordinary methods lacking in technological skills. Students need additional time, experience, and training to embrace the use of m-learning via smartphones.

Despite a growing interest in smartphone use, results indicated that students do not know how to integrate technology (for example, smartphones) with pedagogy to achieve best results and positive impacts (Loveless \& Ellis, 2001). Local and global markets will hire graduates who have higher thinking skills (like creative thinking), 
flexibility, adaptability, problem solving, time management, logical analysis, and other skills offered to students through smartphone technology.

Conclusive scientific evidence on the feasibility of integrating smartphone technology and pedagogy seem important in light of the vast amount of m-learning technological tools and systems. The change in knowledge, accompanied by a development in mobile technological tools, force educational researchers to seek best methods and feasibility aspects to identify effective outcomes in the absence of a clear and established standards or learning theory that might facilitate or guide m-learning technologies like smartphones (Mlitwa, 2005).

Indeed, educational efforts should be directed toward an integration of smartphone technology into student learning processes. The integration of technology in learning and teaching represents a close relationship to the trends surrounding technology. This will impact teaching methods followed both inside and outside of the classroom (Liu, 2010).

\subsection{Statment of The Problem and Research Questions}

While teaching graduate students at The University of Jordan, it was noted that some graduate students were eager to use smartphones during class. This included video recordings, searching the internet, downloading and uploading files, and sharing files with colleagues. This led to the following questions: Why would students choose not to use smartphones in their learning process? What obstacles could limit the student's exploitation of their smartphones in the educational process?

Through the author's experience as an instructor in the educational technology program at The University of Jordan, it was noted that some students were not abreast of developments in m-learning through smartphones. These developments could be exploited in the learning process since they are a keystone in the application of $\mathrm{m}$ learning. This is a modern technological revolution.

The following questions may assist in answering emerging problems:

1. What obstacles hinder student use of smartphones in learning?

2. Are there statistically significant differences in student estimates of obstacles hindering their use of smartphones in learning? These include: gender, age, place of work, first academic degree (BA), and computer skills.

\subsection{Significance of The Study}

This study is significant because:

- It sheds light on an effective and modern learning method in which students are responsible for their learning. This study identifies obstacles and problems facing students who use smartphones in learning.

- It draws attention to the increased use of this new technology within learning environments. 
- It paves the road for researchers, especially those interested in modern technological tools, to conduct similar studies.

\subsection{Operational Definitions}

- Smartphone: A phone that is run by an operating system. It can be compared to a small computer because it combines telephone capabilities, a camera, and a MP3 player. With access to the internet, students use the smartphone to communicate, upload files (i.e., videos, lectures, e-books, homework, tests, etc.), run multi-media playback, access e-mail, view and edit text, send instant messages, and store materials. Often operated by touch, its devices combine communication and computing in a single compact system.

- Learning via Smartphone: This is a personal effort of individual students at The University of Jordan. Using smartphones, students can learn at any time or place and at their own pace (depending on the quality of the smartphone).

- Obstacles: Graduate students at The University of Jordan face challenges and problems when learning new knowledge via smartphone applications.

\subsection{Limitations of the Study}

The outcome for the study and dissemination of its results are based on the following parameters:

1. The study was limited to graduate students in the School of Educational Sciences at The University of Jordan.

2. The study was implemented in the first semester of the 2016-2017 academic year.

3 . The study's results are determined by the extent of the validity and reliability of the study tool.

\section{$2 \quad$ Literature Review}

Learning via smartphone is gaining momentum, especially in terms of new technology. Researchers and educators are eager to examine this new innovation from different perspectives. Many countries and educational institutions conduct experiments, as well as publish research and field studies, in an attempt to develop educational systems employing learning mobile services and their applications.

A study conducted by Ebiye (2015) investigated the impact of smartphones when searching for information by students' in medical colleges and faculty members at Niger Delta University in Nigeria. Conducted as a descriptive survey, the study distributed a questionnaire to a sample of 500 student and faculty members from four colleges. The results showed a high degree of awareness and good use of smartphones among faculty and students when searching for information.

Al-Emran and Shaalan (2015) conducted a study to identify trends of students and faculty members on the use of m-learning in higher education institutions in two 
states of the Arab Gulf countries: the United Arab Emirates (UAE) and the Sultanate of Oman. The study sample consisted of two randomized samples of students and faculty members from five universities in the Gulf region (one at the University of Oman and four from the UAE). The first sample consisted of 383 students from different academic levels, disciplines, and departments. This included 225 participants from the Sultanate of Oman and 158 participants from the UAE. The second sample consisted of 54 instructors with 24 from the Sultanate of Oman and 30 from the UAE. The study utilized a questionnaire to collect data from respondents. It concluded that there were no statistical significant differences between students in terms of attitudes toward the use of m-learning due to gender. There were statistically significant differences between students in terms of attitudes toward the use of m-learning attributed to the country for the benefit of the UAE. Regarding differences between the faculty members, the results indicated that there were no statistically significant differences between them due to gender and country. They were willing to use m-learning in the educational process.

Vázquez-Cano (2014) conducted a study to evaluate the use of smartphone applications and their abilities to promote distance learning. The study sample consisted of 388 students from the Spanish National University. A questionnaire tool was used to collect data. Despite high educational functions for smartphones outside the university campus, the results showed student dissatisfaction for academic courses available on their smartphones. The results confirmed the need to integrate and develop an electronic curriculum while encouraging students and teachers to use smartphones in the educational process. In addition, the results confirmed the importance of allowing the delivery of duties by students, providing evaluations and feedback by teachers, and delivering content and references online through open educational resources. Accessible information on smartphones results in increased learning and communication.

Alomari (2014) conducted a study to explore Jordanian graduate students' utilization of mobile learning applications, obstacles hindering the utilization, and effects of specialization, age, year of study, gender, and average utilization of these applications. A descriptive survey questionnaire with 43 items was distributed to a sample of 342 students from the Faculty of Education at Yarmouk University during the first semester of the 2013-2014 academic year. The findings showed a moderate degree of utilization. In addition, the overall degree level of obstacles was reported as moderate. Both human and technical constraints adversely affected the use of smartphones in learning. These included: university officals banned smartphone use in learning during lectures; instructors did not utilize m-learning; and students were distracted during lectures.

Boruff and Storie (2014) conducted a study to identify the extent of using smartphones and tablets in searching for medical information by students, residents, and faculty members in Canadian medical colleges and hospitals. The study sample consisted of 1,210 participants from medical colleges in four Canadian universities. Data were collected electronically via a questionnaire. The study found that residents in teaching hospitals were more likely to use mobile devices to search for pharmaceutical and medical information (73.5\%). More than half of the respondents $(51.6 \%)$ 
used devices to take notes; half of the respondents $(50.2 \%)$ used them to search for and read scientific papers published in medical journals. The results of the study showed that less than half of the respondents $(47.5 \%)$ used mobile devices more than once a day. Residents came in first place for use $(77 \%)$. They were followed by thirdand fourth-year students (59.1\%) and faculty (38.5\%). In terms of obstacles to the use of mobile devices for educational purposes, results indicated that $70.7 \%$ of respondents reported a weakness of wireless access in the hospital or clinic. The percentage of faculty members in this regard was $66.2 \%$, followed by the non-knowledge of available medical sources that can be utilized and a lack of time for faculty members. Other obstacles included technological problems related to using, downloading, and uploading software.

Jacob (2014) examined the awareness of Nigerian students and faculty members in using smartphones as a tool in learning. The study sample consisted of 50 students and 50 faculty members from the Kogi International College of Education in Nigeria. A questionnaire was used for data collection. The results showed awareness among students and faculty members for smartphone use as a learning tool. However, students and faculty members did not use smartphones in learning and teaching due to a lack of knowledge and training on the technological benefits of smartphones. Another factor was that colleges were unprepared for learning with technology.

Rellinger (2014) conducted a study to compare the responses of faculty members to responses of students toward the use of smartphones and tablets in the educational process. The sample consisted of 76 faculty members and 416 students from Bowling Green State University in the United States. A questionnaire was used for data collection. The results showed that faculty members did not find it difficult to use smartphones and tablets in the academic process and did not feel that smartphones were more complex than other hardware. Students had an internal motivation to use smartphones and tablets to improve the learning process. The study also found that peers influenced the role of smartphone use among students.

Kim, Ilon, and Altmann (2013) conducted a study to reveal how students use smartphones in the learning process. Forty students from South Korea's Seoul National University were interviewed. A questionnaire was also distributed to 86 students. The results showed that smartphones were widely owned by students and that there was a variation in use for learning purposes. In the reseach, $16 \%$ of students who used smartphones had 80 applications dedicated specifically to learning; $47 \%$ of students who used smartphones in learning has 55 applications; and one of the students never used a smartphone in learning. Although there were 25 applications on the smartphones, the results showed that dstudents used an average of 14 application in the learning process. Engineering students used six applications. The most frequently used applications in learning were: dictionary and translation; e-mail; text; media; memos; scheduling; social networking; and internet searches.

A study conducted by Alinizi (2012) explored the use of mobile phone applications in learning, as well as their obstacles. The study was conducted at Taibah University in Saudi Arabia. A questionniare consisted of 43 questions, with two open-ended questions. The study sample consisted of 302 stratified randomly-selected students from different faculties. The study concluded that the use of mobile phone applica- 
tions by students was moderate; students faced a higher degree of obstacles. The highest scored obstacles were: (1) rules and regulations in the university prevent the use of a mobile phone; and (2) many of the faculty members are not convinced of employing mobile phones in the educational process. The students noted that the faculty believed smartphones were a tool for communication and entertainment. Technical obstacles included battery chargers that quickly drained and small data display screens. The results showed a statistically significant difference on student gender (in favor of male students) and faculty type (in favor of computer engineering). There was a lack of statistical significance with regard to school year.

Mtega, Bernard, Msungu, and Sanare (2012) completed a study at the Sokoine University in Tanzania. Their research investigated smartphone use in teaching and learning, specifically studying how smartphones help to facilitate learning and teaching. The study used a descriptive survey approach with a questionnaire applied to a randomly-selected sample of 30 faculty members and 40 students. A semi-structured interviews was conducted. Results showed that the majority of respondents used smartphones for learning and teaching. Many of the faculty members had m-learning applications on their phones allowing them to download and upload files. It also it showed that faculty members lacked awareness toward capacity and the possibility of employing smartphones in teaching.

Suki and Suki (2011) explored the learner's acceptance of m-learning. The researchers designed a questionnaire with five open-ended questions. It was distributed to a stratified random sample of 20 students at the University of Selangor in Malaysia. The results of the study showed that students were not interested in using m-learning. Although they used smartphones, they preferred learning from video-recorded lectures and face-to-face meetings. The study concluded that the students did not expect improvements on the learning process due to m-learning. The students showed a negative attitude toward this technology.

Pollara (2011) conducted a study to identify how students use mobile devices for learning both inside and outside of the classroom. The study also examined student and faculty member impressions on the impact of mobile devices in student learning. Furthermore, the study reviewed the possibility of adopting mobile devices in the classroom. The sample consisted of 308 students and 109 instructors who were surveyed with a questionnaire. Interviews were also conducted with a representative sample from the two groups. The results indicated a mismatch between instructor perceptions on student use of mobile devices compared to actual use. Instructors thought that students used mobile devices for social networking. However, students thought that many educational tasks could be completed using those devices. Some instructors prohibited mobile devices within the classroom and preferred to use mobile learning outside of the classroom. However, students believed that mobile learning was beneficial both inside and outside of the classroom. The results also showed that students were more ready to embrace mobile learning; faculty members needed more time, experience, and training.

Derakhshan (2009) conducted a study to explore how students and faculty use mobile devices in learning and teaching with a focus on their understanding of the advantages of learning management systems via mobile devices. The study sample con- 
sisted of 335 undergraduate students, 129 graduate students, and 52 faculty members from Ohio State University in the U.S. A questionnaire was used to collect data. The results showed that the majority of students used portable mobile devices in the learning process. One-third of students entered courses online three times a week. There was no statistically significant differences due to gender or race. The results showed that faculty members used mobile devices to access the internet. However, half of the faculty members did not teach online. One-third of the faculty members taught at least four courses. The majority of students accessed online courses with mobile devices at least once a day; faculty members preferred to access courses only once a week. The majority of students preferred to access courses as they walked away; faculty members accessed courses from home. The results also showed that students preferred the following features: e-mail, tasks; grading and feedback; ads and news; calendars; discussions; and content. Faculty members preferred the university calendar and discussions.

\section{$2.1 \quad$ Summary}

By reviewing previous studies, the researcher found an absence of Arab studies on $\mathrm{m}$-learning via smartphones. In particular, information was lacking regarding obstacles hindering its use by students in higher education. This also applied to foreign studies. The research noted that some studies discussed m-learning without specifying a particular device. This research agreed with previous studies in terms of using a questionnaire to collect data. This was similar to studies conducted by Alinizi (2012), Boruff and Storie (2014), Derakhshan (2009), Ebiye (2015), Jacob (2014), Mtega et al. (2012), Pollara (2011), and Rellinger (2014).

The study centered on higher education students in a developing country. The study was consistent with previous research in terms of the handling of m-learning. However, it differed in terms of dealing with the areas, extent of use, obstacles, and $\mathrm{m}$-learning devices used in the teaching and learning process. There was also a variation in terms of the application of the study on graduate students.

\section{$3 \quad$ Methodology}

This study used a descriptive survey research method with a self-administered questionnaire. It examined obstacles facing students while using smartphones in learning. It also investigated whether student estimates of obstacles varied with regard to gender, age, place of work, first academic degree (BA), and computer skill.

\subsection{Sample of the Study}

The study sample consisted of 227 graduate students from the School of Educational Sciences at The University of Jordan during the first semester of the 2016-2017 academic year. A total of 108 students with smartphones responded to the questionnaire. This was $45 \%$ of the original study sample. 
Table 1. Demographic distribution of students in the entire ppulation

\begin{tabular}{|c|c|c|c|}
\hline Variable & Group & Number & Percentage \\
\hline \multirow{3}{*}{ Gender } & Male & 37 & 34.3 \\
\hline & Female & 71 & 65.7 \\
\hline & Total & 108 & 100.0 \\
\hline \multirow{3}{*}{ First Degree (BA) } & Scientific & 39 & 36.1 \\
\hline & Humanities & 69 & 63.9 \\
\hline & Total & 108 & 100.0 \\
\hline \multirow{4}{*}{ Place of Work } & Public Sector & 49 & 45.4 \\
\hline & Private Sector & 25 & 23.2 \\
\hline & Unavailable & 34 & 31.5 \\
\hline & Total & 108 & 100.0 \\
\hline \multirow{5}{*}{ Age } & $20-30$ & 63 & 58.3 \\
\hline & $31-40$ & 29 & 26.9 \\
\hline & $41-50$ & 16 & 14.8 \\
\hline & $51+$ & 0 & 0.0 \\
\hline & Total & 108 & 100.0 \\
\hline \multirow{4}{*}{ Computer Skill } & High & 89 & 82.4 \\
\hline & Intermediate & 11 & 10.2 \\
\hline & Low & 8 & 7.4 \\
\hline & Total & 108 & 100.0 \\
\hline
\end{tabular}

\subsection{Study Instrument}

For the purposes of the study, the researcher developed a self-administered questionnaire to examine obstacles facing students while using smartphones in learning. The questionnaire wasbased on previous studies and theoretical literature in the same field. The final questionnaire consisted of 21 items. A five-point Likert scale ranging from (1) strongly agrees to (5) strongly disagrees measured student estimates of obstacles faced while using smartphones in learning.

\subsection{Study Variables}

\section{Independent Variables}

- Gender with two levels: Male, female

- Age, including four levels: 20-30, 31-40, 41-50, 51+

- Place of work, including three levels: Public sector, private sector, not available

- First academic degree (BA) with two levels: Scientific, humanities

- Computer skill with three levels: High, intermediate, low 
Dependant Variables. These variables were measured using student responses on the questionnaire. It reflects student estimates of obstacles faced while using smartphones in learning.

\subsection{Validity}

To verify the face validation of the questionnaire, it was presented in its preliminary copy to a group of specialists and educators. To ensure content validity, the questionnaire was presented to five faculty members who majored in educational technology, curriculum and instruction, and evaluation and measurement at The University of Jordan. They reviewed and judged the list of obstacles faced by students while using smartphones in learning. The questionnaire was then presented in its final version.

\subsection{Reliability}

The reliability of the questionnaire was ensured through measuring the internal consistency (Cronbach's alpha) for the overall scale (0.88). This showed a high internal consistency value. This value is considered appropriate and reasonable for purposes of applying the questionnaire.

\section{$4 \quad$ Results of The Study}

Question 1: What obstacles could hinder student use of smartphones in learning? To answer this question, the means and standard deviations were calculated (see Table 2).

Table 2. Means and standard deviations for obstacles (arranged in descending order)

\begin{tabular}{|c|c|c|c|c|l|c|}
\hline Rank & Level & $\begin{array}{c}\text { Relative } \\
\text { Importance }\end{array}$ & $\begin{array}{c}\text { Standard } \\
\text { Deviations }\end{array}$ & Means & \multicolumn{1}{|c|}{$\begin{array}{c}\text { Items } \\
\text { ber }\end{array}$} \\
\hline 1 & High & 89.00 & 0.78 & 4.45 & $\begin{array}{l}\text { University regulations prohibit using } \\
\text { smartphones in classrooms }\end{array}$ & 17 \\
\hline 2 & High & 88.40 & 0.82 & 4.42 & $\begin{array}{l}\text { High subscription fees for communica- } \\
\text { tions imposed by the mobile operators }\end{array}$ & 7 \\
\hline 3 & High & 86.80 & 0.89 & 4.34 & $\begin{array}{l}\text { Lack of awareness of the importance of } \\
\text { smartphones in learning in part of facul- } \\
\text { ty members }\end{array}$ & 21 \\
\hline 4 & High & 86.40 & 0.96 & 4.32 & $\begin{array}{l}\text { Need for regular battery charge for the } \\
\text { smartphone }\end{array}$ & 5 \\
\hline 5 & High & 85.80 & 0.90 & 4.29 & $\begin{array}{l}\text { Lack of faculty member cooperation in } \\
\text { clarifying smartphone capacities in } \\
\text { learning }\end{array}$ & 9 \\
\hline 6 & High & 85.80 & 0.88 & 4.29 & $\begin{array}{l}\text { Limited power switches for charging } \\
\text { smartphones }\end{array}$ & 10 \\
\hline 7 & High & 85.40 & 0.83 & 4.27 & Limited networks and wireless services & 8 \\
\hline
\end{tabular}


Paper-Smartphones as a New Paradigm in Higher Education Overcoming Obstacles

\begin{tabular}{|c|c|c|c|c|c|c|}
\hline & & & & & inside classrooms & \\
\hline 8 & High & 83.00 & 1.07 & 4.15 & $\begin{array}{l}\text { Rapid advancement of smartphone } \\
\text { models lead to lack of familarity in part } \\
\text { of students }\end{array}$ & 16 \\
\hline 9 & High & 82.00 & 0.78 & 4.10 & $\begin{array}{l}\text { Lack of special training for the use of } \\
\text { smartphones in learning for faculty } \\
\text { members }\end{array}$ & 14 \\
\hline 10 & High & 81.60 & 0.88 & 4.08 & $\begin{array}{l}\text { Most smartphone applications are not } \\
\text { compatible with those on desktop com- } \\
\text { puters }\end{array}$ & 15 \\
\hline 11 & High & 80.40 & 1.01 & 4.02 & $\begin{array}{l}\text { Difficulty in typing and entering data } \\
\text { due to the small size of the keyboard }\end{array}$ & 1 \\
\hline 12 & High & 79.80 & 1.02 & 3.99 & $\begin{array}{l}\text { Smartphones may affect the health of its } \\
\text { user }\end{array}$ & 19 \\
\hline 13 & High & 79.20 & 0.99 & 3.96 & $\begin{array}{l}\text { Concerns of penetrating secure and } \\
\text { private information }\end{array}$ & 13 \\
\hline 14 & High & 78.80 & 1.04 & 3.94 & $\begin{array}{l}\text { Non-availability of specific learning } \\
\text { theories or educational practices to adopt } \\
\text { smartphones in the learning process }\end{array}$ & 12 \\
\hline 15 & High & 77.60 & 1.08 & 3.88 & $\begin{array}{l}\text { Faculty believe they cause distractions } \\
\text { among students during class }\end{array}$ & 2 \\
\hline 16 & High & 74.60 & 1.24 & 3.73 & $\begin{array}{l}\text { University system does not encourage } \\
\text { smartphones in learning }\end{array}$ & 3 \\
\hline 17 & Moderate & 73.20 & 0.97 & 3.66 & $\begin{array}{l}\text { Lack of specialists for the processing of } \\
\text { smartphone learning requirements }\end{array}$ & 20 \\
\hline 18 & Moderate & 72.00 & 1.18 & 3.60 & $\begin{array}{l}\text { Lack of knowledge of smartphone } \\
\text { learning techniques }\end{array}$ & 6 \\
\hline 19 & Moderate & 70.80 & 0.98 & 3.54 & $\begin{array}{l}\text { Lack of academic experience in learning } \\
\text { smartphone applications }\end{array}$ & 11 \\
\hline 20 & Moderate & 69.40 & 1.28 & 3.47 & $\begin{array}{l}\text { Lack of learning activities that support } \\
\text { the employment of smartphones in } \\
\text { learning }\end{array}$ & 4 \\
\hline 21 & Moderate & 64.60 & 1.24 & 3.23 & $\begin{array}{l}\text { Lack of conviction in the usefulness of } \\
\text { smartphones in learning in part of the } \\
\text { students }\end{array}$ & 18 \\
\hline & High & 79.80 & 0.53 & 3.99 & Overall Degree & \\
\hline
\end{tabular}

Table 2 indicates a high level of obstacles facing students when using smartphones in learning. The overall degree of mean was 3.99 with a relative importance of 79.80 . The item's level of the scope was between moderate and high; the mean difference was 3.23-4.45. The first rank of obstacles was for Number 17, "university regulations prohibit using smartphones in classrooms," with a mean of 4.45 and a relative importance of 89.00 . This was followed by Number 7, "high subscription fees for communications imposed by the mobile operators," with a mean of 4.42 and a relative importance of 88.40. The last rank was Number 18, "lack of conviction in the usefulness of smartphones in learning in part of the students" with a mean of 3.23 and a relative importance of 64.60. Number 4, "lack of learning activities that support the employment of smartphones in learning," was ranked before the last with a mean of 3.47 and a relative importance of 69.40 . 
Question 2: Are there any statistically significant differences in student estimates of obstacles that might hinder their use of smartphones in learning with regard to gender, age, place of work, first academic degree (BA), and computer skills?

For this purpose, answers were arranged according to each variable:

Gender: Means and standard deviations were calculated for student estimates of obstacles facing them according to their gender (see Table 3).

Table 3. T-test results of the means difference of obstacles facing students according to their gender

\begin{tabular}{|c|c|c|c|c|c|c|}
\hline \multirow{2}{*}{ Level of Significance } & T-Value & $\begin{array}{c}\text { Standard } \\
\text { Deviation }\end{array}$ & $\begin{array}{c}\text { Mea } \\
\text { ns }\end{array}$ & Number & Gender & \multirow{2}{*}{ Scopes } \\
\hline \multirow{2}{*}{$\mathbf{0 . 0 8}$} & \multirow{2}{*}{$\mathbf{1 . 7 6}$} & 0.56 & 4.11 & 37 & Male & \multirow{2}{*}{ Obstacles } \\
\cline { 3 - 6 } & & 0.50 & 3.92 & 71 & Female & \\
\hline
\end{tabular}

Table 3 shows a lack of statistically significant differences at the level of significance $(\alpha \leq 0.05)$ in student estimates of obstacles while learning via smartphones, attributed to their gender, based on the calculated T-value (1.76), with the level of statistical significance of 0.08 .

Age: Means and standard deviations were calculated for student estimates of obstacles facing them according to their age (see Table 4).

Table 4. Means and standard deviations of obstacles facing students according to their age

\begin{tabular}{|c|c|c|c|c|}
\hline Standard Deviation & Means & Number & Age & \multirow{2}{*}{ Scopes } \\
\hline 0.48 & 3.91 & 63 & $20-30$ & \multirow{2}{*}{ Obstacles } \\
\hline 0.50 & 4.16 & 29 & $31-40$ \\
\hline 0.69 & 3.98 & 16 & $41-50$ & \\
\hline
\end{tabular}

Table 4 shows differences between means of student estimates of obstacles according to their age. To determine whether these differences between means are statistically significant at the significance level $(\alpha \geq 0.05)$, a one-way analysis of variance was applied (see Table 5).

Table 5. Results of a one-way analysis of variance for student age

\begin{tabular}{|c|c|c|c|c|c|c|}
\hline $\begin{array}{c}\text { Level of Signifi- } \\
\text { cance }\end{array}$ & P-Value & Squares Mean & $\begin{array}{c}\text { Degree of } \\
\text { Freedom }\end{array}$ & $\begin{array}{c}\text { Sum of } \\
\text { Squares }\end{array}$ & $\begin{array}{c}\text { Source } \\
\text { of Vari- } \\
\text { ance }\end{array}$ & Scopes \\
\hline \multirow{2}{*}{0.100} & \multirow{2}{*}{2.35} & 0.64 & 2 & 1.28 & $\begin{array}{c}\text { Among } \\
\text { the } \\
\text { groups }\end{array}$ \\
\cline { 3 - 6 } & \multirow{2}{*}{0.27} & 105 & 28.64 & $\begin{array}{c}\text { Within } \\
\text { the } \\
\text { groups }\end{array}$ & $\begin{array}{c}\text { Obsta- ' } \\
\text { cles }\end{array}$ \\
\cline { 3 - 5 } & & & 107 & 29.92 & Total \\
\hline
\end{tabular}


Table 5 shows a lack of statistically significant differences at the level of significance $(\alpha \geq 0.05)$ in student estimates of obstacles attributed to their age, based on the calculated P-value (2.35), with the level of statistical significance of 0.100 . These values are not considered statistically significant.

Place of Work: Means and standard deviations were calculated for student estimates of obstacles according to their place of work (see Table 6).

Table 6. Means and standard deviations of obstacles according to place of work

\begin{tabular}{|c|c|c|c|c|}
\hline Standard Deviation & Means & Number & Place of Work & \multirow{2}{*}{ Scope } \\
\hline 0.56 & 4.04 & 49 & Public sector & Obstacles \\
\hline 0.49 & 3.83 & 25 & Private sector \\
\hline 0.50 & 4.02 & 34 & Not available & \\
\hline
\end{tabular}

Table 6 shows differences between means of student estimates of obstacles according to their place of work. To determine whether these differences are statistically significant at the significance level $(\alpha \geq 0.05)$, a one-way analysis of variance was applied (see Table 7).

Table 7. Results of one-way analysis of variance according to place of work

\begin{tabular}{|c|c|c|c|c|c|c|}
\hline $\begin{array}{c}\text { Level of Signifi- } \\
\text { cance }\end{array}$ & P-Value & $\begin{array}{c}\text { Squares } \\
\text { Mean }\end{array}$ & $\begin{array}{c}\text { Degree of } \\
\text { Freedom }\end{array}$ & $\begin{array}{c}\text { Sum of } \\
\text { Squares }\end{array}$ & $\begin{array}{c}\text { Source of } \\
\text { Variance }\end{array}$ & Scopes \\
\hline \multirow{3}{*}{0.255} & 0.38 & 2 & 0.77 & $\begin{array}{c}\text { Among the } \\
\text { groups }\end{array}$ & \\
\cline { 3 - 5 } & \multirow{2}{*}{1.39} & 0.28 & 105 & 29.15 & $\begin{array}{c}\text { Within the } \\
\text { groups }\end{array}$ & Obstacles ' \\
\cline { 3 - 6 } & & & 107 & 29.92 & Total \\
\hline
\end{tabular}

Table 7 shows a lack of statistically significant differences at the level of significance $(\alpha \geq 0.05)$ in student estimates of obstacles attributed to their place of work, based on the calculated P-value (1.39), with the level of statistical significance of 0.255 . These values are not considered statistically significant.

First Degree (BA) Variable: Means and standard deviations were calculated for student estimates of obstacles according to their first degree (BA) (see Table 8).

Table 8. T-test results of the means difference of obstacles facing students according to first degree (BA)

\begin{tabular}{|c|c|c|c|c|c|c|}
\hline $\begin{array}{c}\text { Level of Signif- } \\
\text { icance }\end{array}$ & T-Value & $\begin{array}{c}\text { Standard } \\
\text { Deviations }\end{array}$ & Means & Number & First Degree (BA) & Scopes \\
\hline \multirow{2}{*}{$\mathbf{0 . 8 5 1}$} & $\mathbf{0 . 1 8}$ & 0.60 & 4.00 & 39 & Scientific & \multirow{2}{*}{ Obstacles } \\
\cline { 3 - 6 } & 0.49 & 3.98 & 69 & Humanities & \\
\hline
\end{tabular}

Table 8 shows a lack of statistically significant differences at the level of significance $(\alpha \geq 0.05)$ in student estimates of obstacles attributed to their first degree (BA), based on the calculated T-value (0.18), with the level of statistical significance of 0.851 . These values are not considered statistically significant. 
Computer Skills Variable: Means and standard deviations were calculated for student estimates of obstacles according to their computer skills (see Table 9).

Table 9. Means and standard deviations of obstacles according to computer skills

\begin{tabular}{|c|c|c|c|c|}
\hline $\begin{array}{c}\text { Standard } \\
\text { Deviations }\end{array}$ & Means & Number & Computer Skills & Scopes \\
\hline 0.53 & 3.98 & 89 & High & \\
\hline 0.46 & 3.83 & 11 & Average \\
\hline 0.55 & 4.26 & 8 & Low \\
\hline
\end{tabular}

Table 9 shows differences between means of student estimates of obstacles according to their computer skills. To determine whether the differences between the means are statistically significant at the significance level $(\alpha \geq 0.05)$, a one-way analysis of variance was applied (see Table 10).

Table 10. Results of the one-way analysis of variance to the means of obstacles according to computer skills

\begin{tabular}{|c|c|c|c|c|c|c|}
\hline $\begin{array}{c}\text { Level of Signif- } \\
\text { icance }\end{array}$ & P-Value & Squares Mean & $\begin{array}{c}\text { Degree of } \\
\text { Freedom }\end{array}$ & $\begin{array}{c}\text { Sum of } \\
\text { Squares }\end{array}$ & $\begin{array}{c}\text { Source of } \\
\text { Variance }\end{array}$ & Scope \\
\hline \multirow{2}{*}{0.221} & \multirow{3}{*}{1.53} & 0.42 & 2 & 0.85 & $\begin{array}{c}\text { Among the } \\
\text { groups }\end{array}$ & \\
\cline { 3 - 6 } & & 0.28 & 105 & 29.07 & $\begin{array}{c}\text { Within the } \\
\text { groups }\end{array}$ & Obstacles \\
\cline { 3 - 6 } & & & 107 & 29.92 & Total & \\
\hline
\end{tabular}

Table 10 shows a lack of statistically significant differences at the level of significance $(\alpha \geq 0.05)$ in student estimates of obstacles attributed to their computer skills, based on the calculated P-value (1.53), with the level of statistical significance of 0.221 . These values are not considered statistically significant.

\section{$5 \quad$ Discussion of Results}

Question 1: What obstacles could hinder student use of smartphones in learning?

The results showed a high degree level of obstacles faced by students while using smartphones in learning. The mean was 3.99 and the level of scope of time ranged between "moderate" and "high." This was similar to Alinizi (2012), which reported a high degree level of obstacles by students. However, the findings do not agree with Alomari (2014), which found a moderate degree level of obstacles reported by graduate students.

This type of learning is still in a growth phase and requires essentials and elements to increase effectiveness and practice. Overcoming obstacles would encourage others to practice its use. 
The highest obstacles are arranged in descending order as follows: Number 17, "university regulations prohibit using smartphones in classrooms," was ranked first and was similar to Alomari's (2014) findings. Next, Number 7, "high subscription fees for communications imposed by the mobile operators," had a mean of 4.42 and a relative importance of 88.40. Number 21, "lack of awareness of the importance of smartphones in learning in part of faculty members," came next. This was followed by Number 5, "need for regualr battery charge for the smartphone," and Number 9, "lack of faculty member cooperation in clarifying smartphone capacities in learning." Number 10 was "limited power switches for charging smartphones."

This illustrated that a change to university policies is important in eliminating obstacles and increasing effectivness of this method of learning. Changes could include: suitable environments and facilities; free network access; and increased attention and awareness among faculty members. The findings for Numbers 17, 7, 21, 5, 9, and 10 are similar to both Alomari (2014) and Alinizi (2012).

Students noted several items as their lowest obstacles. These are arranged in descending order as follows: Number 18, "lack of conviction in the usefulness of smartphones in learning in part of the students," then Number 4, "lack of learning activities that support the employment of smartphones in learning." Next, Number 11, "lack of academic experience in learning smartphone applications," then Number 6, "lack of knowledge of smartphone learning techniques." These represented the lowest obstacles.

By overcoming obstacles, there is an opportunity to increase the effectiveness of this method of learning. It is also valuable to enrich the university environment to promote modern technology. The university should operate within this framework to amend legislation and laws to give students a chance to officially practice this method of learning.

According to this research, students want university officials to provide suitable environments for the use of smartphones in learning. By examining student responses to the questionnaire, the researcher noticed the university's lack of interest and enthusiasm in enhancing the environment and infrastructure for smartphone learning.

The researcher noted that the items with the highest ratings in student estimates failed within the category of human (rather than material) obstacles. There is a close relationship between new technological influences on culture and modern educational theories and practices as reported by Sharples et al. (2006).

Student estimates of obstacles that scored high were related to their faculty members (see Numbers 9, 14, 21, and 2). The researcher advocated that the pedagogical beliefs of faculty members about the use of smartphone technology are affected by several factors. These factors are similar convictions summarized by Bingimlas (2009), Cuban (1998), Ertmer (2005), Liu (2010), Prestridge (2010), and Tsai and Chai (2012):

1. Lack of training for faculty on how to integrate smartphone technology into teaching and learning

2. Career burden and lack of learning time prevents faculty from embracing change toward smartphones 
3. Poor infrastructure

4. Limited availability of technical and administrative support for faculty

5. Poor design and technological skills, as well as negative trends by faculty

In some cases, faculty members trend positively toward the use of technologies (including smartphones) in teaching and learning. However, obstacles limit the possibility of effectively using technology in teaching and learning (Bingimlas, 2009).

Technology and pedagogy have a reciprocal relationship. Pedagogy affects the selection and organization of technological tools and their use in educational contexts (Loveless \& Ellis, 2001). The importance of focusing on the beliefs of faculty in terms of educational technology and its relationship with pedagogy, that the beliefs of the faculty have a major role in bringing about radical changes in the educational enterprise culture, and practices within them, and in the performance and behavior of students; as the performance of students represent an important indicator that demonstrate the success of the process merger between technology and teaching, despite the presence of other factors (Higgins \& Moseley, 2001).

Student estimates of obstacles scored high and were related to the culture of the university. Manifested in Numbers 3 and 17, the researcher attributed them to the following rationalization. Educators point out that a change in educational environments will take time and occur in successive phases (Fullan, 1991; Rogers, 1995; Somekh, 2007). Changes often occur as a result of a specific need. Rogers (1995) noted varying reactions toward change. For example, creative individuals (innovators) take risks and quickly accept innovative change. In contrast, late people (late adopters) do not easily accept change and take longer to adopt.

To support student endeavors toward adopting smartphones in learning, The University of Jordan must be recognized as a local and international center which embraces the value of its students, society, and country. At the institutional level, the university's mission should be to lead in m-learning development and implementation in higher education. The university should focus appropriate, cost-effective mlearning for workforce development in various trades and professions. All university students should graduate with information technology skills needed in the digital era.

On the other hand, student estimates of obstacles scored moderate and related to the academic departments in Numbers 4, 6, 11, and 20. For academic departments, the researcher proposes that programs in every department should develop a vision for teaching and learning. This should approved by the dean and vice president. A plan for the role of m-learning and smartphone applications should be developed within each program. The vision should be reviewed and revised every three years to keep pace with innovations and technological initiatives.

Student estimates of obstacles scored high and were related to the university administration in Numbers 5, 7, 8, 10, 12, 13, 16, and 19. At the administrative level, students should be able to access all educational services using their smartphones. Academic information should be publicly available with permitted privacy and security. With these preliminary steps in place, the plan would then move toward an integration of smartphones into learning. According to Bingimlas (2009), lack of training 
and technical support at the administrative level would present obstacles in the integration of these new technologies.

Although Numbers 1 and 15 scored high in student estimates of obstacles, they are associated with technical issues and smartphone capablities. It is beyond the responsibility of the academic and services sectors to suggest a pardigm for solutions.

Finally, Number 18 scored moderate in student estimates of obstacles. The researcher attributed this to smartphone in the Jordanian society and in university students. Students use smartphones for networking, high-quality multimedia, personal computing devices, messages, news, games, music, editing, and accessing net services (internet browsing, registering courses, library services, paying tution fees, etc.). Inclination to own and use smartphones in learning should be fostered. A suitable pradigm for smartphone integration into learning should be adopted.

Question 2: Are there any statistically significant differences in student estimates of obstacles that might hinder their use of smartphones in learning with regard to gender, age, place of work, first academic degree (BA), and computer skills?

The answer will be arranged according to each variable:

1. Gender: The results indicated no statistically significant differences at the level of significance $(\alpha \leq 0.05)$, where the calculated level of significance value was greater than 0.05 . This showed that obstacles were convergent for both genders. This is attributed to the fact that students received the same academic and cognitive level as in previous stages.

2. Age: After calculating the means and standard deviations of student estimates of obstacles according to their age, the researcher observed differences between the means of student estimates of obstacles according to their age. To determine whether the differences between the means are statistically significant at the significance level ( $\alpha \geq 0.05$ ), a one-way analysis of variance was applied. The results showed no differences based on the calculated P-value. These valueswere not statistically significant because the level of statistical significance calculated was greater than 0.05 . Hence, age is not considered a factor in the perspective of students to these obstacles.

3. Place of Work: There were differences in means according to place of work. To determine whether differences between the means are statistically significant at the significance level $(\alpha \geq 0.05)$, a one-way analysis of variance was applied. The results showed no statistically significant differences of obstacles attributable to the place of work based on the calculated P-value (1.39) with the level of statistical significance of 0.255 . The researchers attributed this to the fact that most of the students were centralized in the working class (public sector). The remaining were distributed among other groups. Therefore, their view of obstacles did not vary according to this variable, especially with the nature of work requirements, conditions, needs, and systems.

4. First Degree (BA): The results indicated no statistically significant differences at the level of significance $(\alpha \leq 0.05)$ that were attributable to this variable based on the calculated T-value $(0.18)$ with the level of statistical significance of 0.851 . These values are not considered statistically significant because the level of statis- 
tical significance calculated was greater than 0.05 . The results also indicated that the perspective of the student does not vary according to their first degree. The researcher attributed this to the fact that their major before the master's level was convergent, as the majority focused in the humanities.

5. Computer Skills: The results indicated differences among the means. To determine whether the differences are statistically significant at the significance level $(\alpha$ $\geq 0.05$ ), a one-way analysis of variance was applied. The results showed no statistically significant differences at the significance level $(\alpha \geq 0.05)$ in obstacles attributed to student computer skills based on the calculated P-value (1.53) with the level of statistical significance of 0.221 . These values were not statistically significant because the level of statistical significance calculated was greater than 0.05 . The researcher attributed this to the fact that most of the students had computer skills; 89 of the students were in the "high" category. Therefore, this variable made no difference in student responses.

\section{Recommendations}

Based on its results, the study came to the following conclusions:

1. Provide an appropriate, supportive, enriched environment for this method of learning in universities.

2. Conduct further research and studies on learning via smartphones, its practice principles, and its supporting factors.

\section{$7 \quad$ References}

[1] Abdelmajid, H. (2008). Developing and evaluating of interactive e-learning systems for computer and engineering courses (Unpublished master's thesis). The Arabian Academy, Denmark.

[2] Aldahshan, J., \& Younis, M. (2009, April). Mobile learning a new formula for distance education. The First Scientific Symposium of the Department of Comparative Education and Educational Administration: Higher Education Virtual Systems. Symposium conducted at the Faculty of Education, Kafrelsheikh University, Egypt.

[3] Al-Emran, M., \& Shaalan, K. (2015). Attitudes towards the use of mobile learning: A case study from the Gulf region. International Journal of Mobile Technologies, 9(2), 75-78. https://doi.org/10.3991/ijim.v9i3.4596

[4] Alhalafawi, W. (2011). E-learning innovated applications. Qairo, Dar Afikir Alarabi.

[5] Alhourani, G., \& Tanash, S. (2007). Ethics of academic university professor from the standpoint of faculty members at the University of Jordan. Dirasat, 34(2), 357-388.

[6] Alinizi, S. (2012). The degree of mobile phones applications use by the University of Taibah in the Kingdom of Saudi Arabia and their obstacles to use (Unpublished master's thesis). Graduate Faculty of Louisiana State University, Louisiana.

[7] Alkhozim, K. (2012). Effectiveness of using the balck board mobile program for mobile learning in interaction and academic achievement of students in the development of methods of teaching mathematics course at Teachers College at King Saud University (Unpublished doctoral dissertation). University of Imam Muhammad, Saudi Arabia. 
[8] Alomari, M. (2014). The degree of the utilization of mobile learning applications by graduate students at the Faculty of Education in Yarmouk University \& the obstacles to such utilization. Almanarah, 20(1), 269-300.

[9] Arabiat, G., \& Adaileh, A. (2008). University student rights and duties: Al-Balqa' Applied University as a model. In Proceedings of the Second Cultural Congress - University Youth and the Challenges of Modernity and Tradition (vol. 1, pp. 342-355). Princess Sumaya University for Technology, Amman.

[10] Bingimlas, K. A. (2009). Barriers to the successful integration of ICT in teaching and learning environments: A review of the literature. Eurasia Journal of Mathematics, Science \& Technology Education, 5(3), 235-245. Retrieved November 22, 2016 from www.ejmste.com/v5n3/eurasia v5n3 bingimlas.pdf

[11] Boruff, J., \& Storie, D. (2014). Mobile devices in medicine: A survey of how medical students, residents, and faculty use smartphones and other mobile devices to find information. Journal of the Medical Library Association, 102(1), 22-30. https://doi.org/10.3163/1536$\underline{5050.102 .1 .006}$

[12] Cuban, L. (1998). How schools change reforms: Redefining reform success and failure. Teachers College Record, 99(3), 453-477.

[13] Derakhshan, N. (2009). Student and name faculty career of the features of mobile learning management systems in the context of higher education (Unpublished doctoral dissertation). Multimedia University, Cyberjaya, Selangor, Malaysia.

[14] Deubel, P. (2009, March 19). Mobile devices: Facing challenges and opportunities for learning. THE Journal. Retrived November 22, 2016 from https://thejournal.com/articles/2009/03/19/mobile-devices-facing-challenges-andopportunities-for-learning.aspx

[15] Dewey, J. (1916). Democracy and education. New York, NY: Free Press.

[16] Ebiye, E. V. (2015). Impact of smartphones tablets on the information seeking behaviour of medical students and staff of Niger Delta University Bayelsa State - Nigeria. Library Philosophy and Practice (e-journal). Retrieved June 25, 2016 from http://goo.gl/KhmY8J

[17] Ertmer, P. A. (2005). Teacher pedagogical beliefs: The final frontier in our quest for technology integration? Educational Technology Research and Development, 53(4), 25-39. https://doi.org/10.1007/BF02504683

[18] Fullan, M. (1991). The new meaning of educational change ( $2^{\text {nd }}$ ed.). New York, NY: Teachers College Press.

[19] Higgins, S., \& Moseley, D. (2001). Teachers' thinking about information and communications technology and learning: Beliefs and outcomes. Teacher Development, 5(2), 191210. https://doi.org/10.1080/13664530100200138

[20] ITU News. (2011). Mobile devices on the rise. Retrieved September 10, 2016 from https://itunews.itu.int/en/533-Mobile-devices-on-the-rise.note.aspx

[21] Jacob, O. (2014). Awareness of Nigerian students and teachers about potential use of cell phone as a teaching aid. British Journal of Education, Society \& Behavioral Science, 4(5), 647-655. https://doi.org/10.9734/BJESBS/2014/7754

[22] Kim, J., Illon, L., \& Altmann, J. (2013). Adapting smartphones as learning technology in a Korean University. Journal of Integrated Design and Process Science, 17(1), 5-16.

[23] Liu, S.H. (2010). Correlation between teachers' pedagogical beliefs and teaching activities on technology integration. In Z. Abas, I. Jung \& J. Luca (Eds.), Proceedings of Global Learn 2010 (pp. 892-898). Association for the Advancement of Computing in Education (AACE). Retrieved September 9, 2016 from https://www.learntechlib.org/p/34280

[24] Loveless, A., \& Ellis, V. (2001). ICT, pedagogy and the curriculum. Journal of Computer Assisted Learning, 19, 141-143. 
[25] Mehdipour, Y., \& Zerehkafi, H. (2013). Mobile learning for education: Benefits and challenges international. International Journal of Computational Engineering Research, 3(6), 93-101.

[26] Mtega, W., Bernard, R., Msungu, A. C., \& Sanare, R. (2012). Using mobile pones for teaching and learning purposes in higher learning institutions: The case of Sokoine University of Agriculture in Tanzania. In Proceedings and Report of the 5th UbuntuNet Alliance Annual Conference (pp. 118-129). Sokoine University Agriculture, MorogoroTanzania. Retrieved October 8, 2016 from https://goo.gl/GIS77n

[27] Mlitwa, N. (2005). Global perspectives on higher education and the role of ICT [PDF]. Retrieved October 8, 2016 from http://eprints.rclis.org/6716/1/Global Perspective on Higher Education and the Role of ICT\%E2\%80\%A6.pdf

[28] Pollara, P. (2011). Mobile learning in higher education: A glimpse and a comparison of student and faculty readiness, attitudes and perceptions (Unpublished doctoral dissertation). Graduate Faculty of Louisiana State University, Louisiana.

[29] Prestridge, S. (2010). ICT professional development for teachers in online forums: Analysing the role of discussion. Teaching and Teacher Education, 26(2), 252-258. https://doi.org/10.1016/j.tate.2009.04.004

[30] Rellinger, B. (2014). The diffusion of smartphones and tablets in higher education: Comparison of faculty and student perceptions and uses (Unpublished doctoral dissertation). Graduate Faculty of Louisiana State University, Louisiana.

[31] Rogers, E. M. (1995). Diffusion of innovations (4th ed.). New York, NY: The Free Press.

[32] Sahtot, E. (2014). Designing and producing e-learning resources. Rihyadh, Alrashid Library.

[33] Sharples, M., Taylor, J., \& Vavoula, G. (2006). A theory of learning for the mobile age. In R. Andrews \& C. Haythornthwaite (Ed.), The Sage handbook of Elearning research (pp. 221-247). London, UK: Sage.

[34] Shuler, C. (2009, January). Industry brief: Pockets of potential: Using mobile technologies to promote children's learning. New York: The Joan Ganz Cooney Center at Sesame Workshop. Retrieved on November 16, 2016 from http://joanganzcooneycenter.org/pdf/ pockets of potential.pdf

[35] Somekh, B. (2007). Pedagogy and learning with ICT: Researching the art of innovation. New York, NY: Routledge.

[36] Suki, N. M., \& Suki, N. M. (2011). Using mobile device for learning: From students' perspective. A US-China Education Review, 1, 44-53.

[37] The University of Jordan. (2016). UJ continues to advance on QS ranking. Retrieved on September 15, 2016 from http://ujnews2.ju.edu.jo/en/english/Lists/News/Disp Form News $1 . \operatorname{aspx}$ ?ID=5253

[38] Tsai, C. C., \& Chai, C. S. (2012). The "third"-order barrier for technology integration instruction: Implications for teacher education. In C. P. Lim \& C. S. Chai (Eds.), Building the ICT capacity of the next generation of teachers in Asia. Australasian Journal of Educational Technology, 28(6), 1057-1060.

[39] Vázquez-Cano, E. (2014). Mobile distance learning with smartphones and apps in higher education. Educational Sciences: Theory \& Practice, 14(4), 1505-1520.

[40] Waters, J. K. (2009). IT security: Target: The Web. T.H.E. Journal, 36(2), 34-40. 


\section{Author}

Dr. Mansour Alwraikat is an associate professor of Educational Technology at The University of Jordan in Amman, Jordan, School of Educational Sciences, Department of Curriculum and Instruction.

Article submitted 10 February 2017. Published as resubmitted by the author 18 March 2017. 